Jurnal Media Analis Kesehatan, Vol. 10, No.1, Juni 2019

http://journal.poltekkes-mks.ac.id/ojs2/index.php/mediaanalis

e-ISSN : 2621-9557

p-ISSN : 2087-1333

\title{
ANALISIS JUMLAH PEMERIKSAAN LIMFOSIT PADA PENDERITA HUMAN IMMUNODEFISIENCY VIRUS (HIV)
}

\author{
Prawansa Amran ${ }^{1}$, Andi Wais AL. Qarni ${ }^{2}$ \\ 1,2, Jurusan Analis Kesehatan Poltekkes Kemenkes Makassar
}

Koresponden: amranprawansa67@gmail.com

\begin{abstract}
ABSTRAK
Virus HIV merupakan Virus yang menyerang system kekebalan tubuh, sedangkan sistem kekebalan tubuh bertugas untuk melindungi tubuh dari penyakit apa pun yang setiap hari menyerang tubuh kita. Virus HIV Menyerang Sel darah putih yaitu Limfosit $\mathrm{T}$ sehingga terjadi penurunan Limfosit $\mathrm{T}$ dalam sirkulasi darah, Limfosit dibagi menjadi dua yaitu limfosit $\mathrm{T}$ dan Limfosit $\mathrm{B}$ sehingga peneliti ingin membuktikan hal tersebut dengan menghitung limfosit total pada sediaan apus darah dari penderita Virus HIV. Tujuan penelitian ini adalah untuk mengetahui jumlah limfosit pada penderita HIV. Penelitian ini dilakukan pada tanggal 21 juni - 7 juli 2018 menggunakan jenis penelitian Observasi laboratorium. Dalam penelitian ini menggunakan sampel sebanyak 15 sampel yang diperoleh dari populasi penderita HIV menggunakan teknik total sampling. Analisa data dalam penelitian ini data yang diperoleh dari hasil penelitian Analisis Jumlah pemeriksaan Limfosit pada penderita HIV akan disajikan dalam bentuk tabel dan dianalisis scara deskriptif kemudian dinarasikan. Setelah dilakukan analisa data dapat disimpulkan bahwa didapatkan hasil $26.66 \%$ yang menunjukkan jumlah Limfosit yang Normal dan $73.33 \%$ yang menunjukkan jumlah Limfosit dibawah normal.
\end{abstract}

Kata Kunci : Limfosit, HIV

\section{PENDAHULUAN}

HIV merupakan singkatan dari

Human Immunodefisiency Virus atau yang disingkat dengan HIV, sedangkan AIDS merupakan singkatan dari Acquaired Immune Deficiency Syndrome. Jadi HIV (Human Immunodefisiency Virus) merupakan virus yang menyebabkan penyakit AIDS, dan untuk memudahkan disebut juga sebagai penyakit HIV/AIDS (Hawari D, 2006).

HIV (Human Immunodefisiency

Virus) merupakan salah satu masalah kesehatan yang sering terjadi di Negara berkembang (coovadia \& Hadingham, 2005), termasuk Indonesia. Pada tahun 2005-2015, kejadian kasus HIV semakin meningkat, pada 10 tahun terakhir ditemukan ada 184.929 kasus HIV/AIDS yang dilaporkan (Kepmenkes, 2016). Perkembangan kasus HIV/AIDS menjadi tantangan besar untuk daerah-daerah yang sedang berkembang (Rahayu dkk, 2017).

Berdasarkan usia kasus HIV/AIDS di Indonesia paling banyak diderita oleh usia produktif 25-29 
tahun, dan usia remaja 15-19 tahun menduduki posisi kelima (Infodatin, 2014). Usia remaja merupakan usia yang sangat rentang untuk terinfeksi HIV. Lebih dari setengah infeksi baru HIV didunia ditemukan pada usia 15 19 tahun, dan mayoritas remaja terinfeksi karena hubungan seksual (Guindo dkk, 2014).

Jumlah kasus HIV di Indonesia tumbuh dengan cepat, baik dari sisi wilayah penyebaran maupun pola penyebaran. Dari sisi wilayah, Virus HIV telah menyebar ke hampir seluruh wilayah di Indonesia. Jika pada awalnya hanya provinsi-provinsi tertentu saja yang rawan terhadap penyebaran Virus HIV, sekarang tidak ada lagi provinsi yang kebal terhadap penyebaran virus tersebut (KPAN, 2007), terutama Provinsi Sulawesi selatan tepatnya Kota Makassar.

Kota Makassar merupakan Ibu kota Sulawesi selatan yang memiliki jumlah penderita HIV sebanyak 6.760 kasus, sedangkan penderita AIDS sebanyak 2.542 kasus. Angka ini merupakan data akumulatif dari tahun 2005 sampai juni 2017 (Padmasari, 2017).

HIV dapat menyebabkan masyarakat kehilangan harapan mereka (Akol,2000). Penyakit yang menyerang system kekebalan tubuh manusia ini memungkinkan munculnya berbagai jenis infeksi oportunistik (Rahayu dkk, 2017).

HIV ditularkan melalui kontak seksual, pemaparan darah atau produk darah yang terkontaminasi dengan cara parenteral, dan dari ibu ke anak selama masa pariental (Sastrawinata, 2008). Virus masuk kedalam sel inang berkaitan dengan struktur permukaan virus dan inang, Sebelum terjadi ikatan spesifik antara partikel virus dan permukaan sel inang, berlangsung terjadi penempelan yaitu permukaan molekul gp120 dengan molekul CD4 ${ }^{+}$ yang dimiliki sel inang. demikian molekul $\mathrm{CD}^{+}$yang sangat penting dalam proses respon imun.(Subowo, 2010). Menurut Sastrawinatara, 2008 $\mathrm{CD} 4^{+}$merupakan reseptor utama untuk HIV.

Dalam folikel limfoid, virus terkonsentrasi dalam bentuk kompleks imun yang diikat sel dentritik, destruksi sel $\mathrm{CD}^{+}$berjalan terus dalam kelenjar limfoid. Akhirnya jumlah $\mathrm{CD}^{+}$dalam sirkulasi menurun. Dengan menurunnya jumlah sel $\mathrm{CD}^{+}$, penderita menunjukkan gejala klinis antibody HIV spesifik dengan sel $\mathrm{T}$ sitotoksin menurun, sedang P24 meningkat. Perjalanan infeksi HIV ditandai oleh beberpa fase yang berakhir dalam defisiensi imun. Aktifasi poliklonal Sel B menimbulkan hipergamaglobulinemia, antibody yang menetralkan antigen gp120 diproduksi tetapi tidak mencegah mutasi virus yang tinggi, terjadi abnormal fungsi Sel $B$, jumlah sel B yang memproduksi antibody meningkat dan adanya hipergamaglobulinemia (Widodo W, 2012).

Virus HIV ini menyerang system kekebalan tubuh, sedangkan sistem kekebalan tubuh bertugas untuk melindungi tubuh dari penyakit apa pun yang setiap hari menyerang tubuh kita. Antibodi adalah protein yang dibuat oleh system kekebalan tubuh ketika benda asing masuk kedalam tubuh (murni dkk, 2016). Yang dimaksud 
dalam system pertahan tubuh disini yaitu Sel Leukosit, khususnya Limfosit.

Limfosit adalah sel yang kompeten secara imunologik dan membantu fagosit dalam pertahanan tubuh terhadap infeksi dan invasi asing lain. Virus HIV ini dapat menyerang Limfosit . (Subowo, 2010).

Berdasarkan latar belakang diatas maka peneliti telah tertarik melakukan penelitian tentang pemeriksaan jumlah Limfosit pada Penderita HIV.

\section{METODE}

Penelitian ini adalah Observasi Laboratorium. Penelitian ini dilakukan di Laboratorium Hematologi Jurusan Analis Kesehatan Politeknik Kesehatan Kementerian Kesehatan Makassar pada bulan November 2018

Sampel dari Penelitian ini yaitu Penderita Penyakit HIV sebanyak 15 sampel penderita HIV. Teknik pengambilan sampel menggunakan teknik total sampling.

Instrumen Penelitian yang digunakan dalam penelitian ini adalah: Spoit $3 \mathrm{ml} /$ vacutainer, turnicet (pembendung), tabung $\mathrm{K}_{2}$ EDTA (tutup ungu), Objek glass, Rotator, Pipet tetes, Gelas kimia, batang pengaduk, bak pewarnaan, Alat Penghitung Mikroskop. Sedangkan bahan yang digunakan adalah Methanol, Zat warna Giemsa, Buffer, Darah dan $\mathrm{K}_{2}$ EDTA.

\section{Prosedur Penelitian}

\section{Pra Analitik}

Persiapan pasien pada penelitian ini Tidak memerlukan persiapan Khusus namun pada Persiapan Sampel yang digunakan yaitu Darah EDTA(etilen diamin tetra asetat). EDTA cair dengan konsentrasi $10 \%$ dapat dipakai karena tidak berpengaruh terhadap morfologi eritrosit dan leukosit serta mencegah trombosit bergumpal. Tes sebaiknya dilakukan dalam waktu kurang dari 12 jam. Tiap $1 \mathrm{ml}$ EDTA digunakan untuk $1 \mathrm{ml}$ darah Vena

2. Analitik

a. Pembuatan Sediaan Apus

1) Dipilih objek glass yang bertepi rata untuk digunakan sebagai "kaca penghapus".

2) Satu tetes darah diletakkan pada $\pm 2-3 \mathrm{~mm}$ dari ujung kaca objek.

3) Kaca penghapus diletakkan pada objek dengan posisi 30$45^{0}$ derajat didepan tetes darah.

4) Kaca penghapus ditarik kebelakang, ditunggu sampai darah menyebar pada sudut tersebut.

5) Dengan kaca penghapus didorong sehingga terbentuk apusan darah sepanjang 3-4 cm kaca objek. Darah harus habis sebelum kaca penghapus menjapai ujung kaca objek. Apusan darah tidak boleh terlalu tipis ataupun terlalu tebal.

6) Apusan darah dibiarkan mengering di udara.

b. Cara mewarnai sediaan apus pewarnaan Giemsa

1) Diletakkan sediaan apus pada bak pewarnaan

2) Difiksasi sediaan apus darah dengan methanol 3 menit/hingga mengering. 
3) sediaan apus digenangi dengan zat warna giemsa yang baru diencerkan. Larutan giemsa yang dipakai adalah 5\% diencerkan dulu dengan larutan dapar $\mathrm{pH} 6,4$, sebagai pengganti larutan dapar, dapat dipakai air suling yang pHnya diatur dengan penambahan tetes demi tetes larutan Kalium bikarbonat $1 \%$ atau larutan HCL $1 \%$, biarkan selama 30 menit

4) Bilas dengan air mengalir, mula-mula dengan aliran lambat kemudian lebih kuat dengan tujuan menghilangkan semua kelebihan zat warna. Letakkan sediaan apus dalam rak dengan posisi tegak dan biarkan mengering.

c. Cara menghitung jenis leukosit
1) Dilakukan pembacaan dengan menggunakan differensial Cell Counter

2) Pembacaan dengan menggunakan Mikroskop pada perbesaran okuler $10 \mathrm{X}$ dan obejktif $100 \mathrm{X}$ dengan bantuan oil imersi.

3) Dimulai menghitung pada sediaan yang bagian tipis.

4) Kemudian dilakukan secara terus menerus sampai 100 sel leukosit dihitung menurut jenisnya.

3. Pasca analitik

Mencatat hasil pemeriksaan yang dilakukan sesuai banyaknya sampel dan Dari hasil pengamatan yang dilakukan dapat memberikan hasil menghitung jumlah leukosit dalam bentuk \%. Nilai Normal hasil Hitung Jenis Leukosit

Daftar tabel 1 Nilai normal jenis sel Leukosit

\begin{tabular}{lcc}
\hline No & Jenis Limfosit & Nilai Normal \\
\hline 1 & Basofil & $0-1 \%$ \\
2 & Eosinofil & $1-3 \%$ \\
3 & Neutrofil batang & $2-6 \%$ \\
4 & Neutrofil Segmen & $50-70 \%$ \\
5 & Limfosit & $20-40 \%$ \\
6 & Monosit & $2-8 \%$ \\
\hline
\end{tabular}

Sumber : (Gandasoebrata, 2011).

Analisa Data

Analisa data dalam penelitian ini yaitu data yang diperoleh dari hasil penelitian Studi hasil pemeriksaan Limfosit pada penderita HIV akan dikumpulkan kemudian disajikan dalam bentuk tabel dan dianalisis secara deskriptif kemudian dinarasikan.

\section{HASIL}

Penelitian ini mengenai Studi Hasil Pemeriksaan Jumlah Limfosit Pada penderita Human Immunodefisiency Virus (HIV) Di Kota Makassar didapatkan sampel dari populasi penderita HIV sebanyak 15 sampel yang dikumpulkan di Puskesmas Jongaya dan Puskesmas Jumpandang baru. Pengumpulan data ini diperoleh dengan pengambilan data 
primer yang secara langsung diambil dari objek dan diperoleh dari hasil percobaan di Laboratorium.
Hasil pemeriksaan disajikan dalam bentuk tabel dari gambar sebagai berikut.

Tabel 2. Hasil Pemeriksaan Jumlah Limfosit Pada penderita Human Immunodefisiecy Virus (HIV) Di Kota Makassar.

\begin{tabular}{cccccc}
\hline No & $\begin{array}{c}\text { Kode } \\
\text { Sampel }\end{array}$ & JK & Umur & $\begin{array}{c}\text { Hasil } \\
\text { Pemeriksaan } \\
\text { Limfosit }\end{array}$ & Keterangan \\
\hline 1 & A & P & 51 & $13 \%$ & Menurun \\
2 & B & L & 29 & $18 \%$ & Menurun \\
3 & C & L & 22 & $17 \%$ & Menurun \\
4 & D & P & 27 & $15 \%$ & Menurun \\
5 & E & P & 29 & $26 \%$ & Normal \\
6 & F & L & 23 & $19 \%$ & Menurun \\
7 & G & P & 31 & $16 \%$ & Menurun \\
8 & H & L & 35 & $13 \%$ & Menurun \\
9 & I & L & 61 & $23 \%$ & Normal \\
10 & J & P & 29 & $12 \%$ & Menurun \\
11 & K & L & 30 & $24 \%$ & Normal \\
12 & L & P & 50 & $18 \%$ & Menurun \\
13 & M & L & 22 & $16 \%$ & Menurun \\
14 & N & P & 29 & $25 \%$ & Normal \\
15 & O & P & 29 & $12 \%$ & Menurun \\
\hline
\end{tabular}

Catatan : Nilai Normal dari Limfosit (20\% - 40\%)

Tabel 2 di atas menunjukkan hasil pemeriksaan jumlah Limfosit pada penderita Human Immunodefisiency Virus (HIV) di kota Makassar. dari 15 sampel terdapat hasil pemeriksaan Limfosit $26.66 \%$ yang terdiri dari 4 sampel menunjukkan jumlah Limfosit yang Normal dan 73.33\% yang terdiri dari 11 sampel menunjukkan jumlah limfosit dibawa normal.

\section{PEMBAHASAN}

HIV merupakan singkatan dari Human Immunodefisiency Virus atau yang disingkat dengan HIV, sedangkan AIDS merupakan singkata dari
Acquaired Immune Deficiency Syndrome. Jadi HIV(Human Immunodefisiency Virus) merupakan virus yang menyebabkan penyakit AIDS, dan untuk memudahkan disebut juga sebagai penyakit HIV/AIDS. HIV/AIDS adalah penyakit kelamin yang 10 tahun mendatang belum ditemukan obatnya. Semua penyakit yang disebabkan virus termasuk influenza belum ditemukan obatnya. Orang yang terkena HIV/AIDS daya tahan atau imunitas tubuhnya menurun sedemikian rupa hingga orang tersebut meninggal (Hawari D, 2006).

HIV ditularkan melalui kontak seksual, pemaparan darah atau produk darah yang terkontaminasi dengan cara 
parenteral, dan dari ibu ke anak selama masa pariental (Sastrawinata, 2008). Darah merupakan medium transport tubuh, volume darah manusia sekitar 7$10 \%$ berat badan normal dan berjumlah sekitar 5 liter. Keadan jumlah darah pada tiap-tiap orang tidak sama, bergantung pada usia, pekerjaan, serta keadaan jantung atau pembuluh darah. (Handayani W dkk, 2008).

Limfosit adalah sel-sel yang kompeten secara imunologik yang membantu fagosiit dalam pertahanan tubuh terhadap infeksi dan invasi benda asing lain. Dua ciri unik yang khas untuk sistem imun adalah kemampuan untuk menimbulkan spesifisitas antigen dan fenomena inkatan imunologik.

Limfosit memiliki nucleus besar bulat dengan menempati sebagian besar Limfosit berkembang dalam jaringan limfe. Ukuran bervariasi dari 7 sampai dengan 15 mikron. Banyaknya 20-40\% dan fungsinya membunuh dan memakan bakteri yang masuk ke dalam jaringan tubuh, limfosit ada 2 macam yaitu limfosit $\mathrm{T}$ dan limfosit $\mathrm{B}$. (Hoffbrand.A.V dkk, 2011).

Jika melihat tabel 4.1 menunjukkan bahwa $26.66 \%$ sampel yang menunjukkan jumlah Limfosit yang Normal dan $73.33 \%$ sampel yang menunjukkan jumlah Limfosit dibawah normal, penderita yang jumlah limfosit yang normal merupakan pasien yang sudah lama menderita virus HIV dan sudah menjalani pengobatan yang rutin sehingga sistem pertahanan tubuh penderita menjadi lebih baik.

Hasil penelitian ini sesuai dengan pernyataan Widodo W,2012 dan Murni dkk,2016, yang menyatakan bahwa Dalam folikel limfoid, virus terkonsentrasi dalam bentuk kompleks imun yang diikat sel dentritik, destruksi sel $\mathrm{CD}^{+}$berjalan terus dalam kelenjar limfoid. Akhirnya jumlah $\mathrm{CD}^{+}$dalam sirkulasi menurun. Dengan menurunnya jumlah sel $\mathrm{CD}^{+}$, penderita menunjukkan gejala klinis antibody HIV spesifik dengan sel $\mathrm{T}$ sitotoksin menurun, sedang P24 meningkat. Perjalanan infeksi HIV ditandai oleh beberpa fase yang berakhir dalam defisiensi imun. Aktifasi poliklonal Sel B menimbulkan hipergamaglobulinemia, antibody yang menetralkan antigen gp120 diproduksi tetapi tidak mencegah mutasi virus yang tinggi, terjadi abnormal fungsi Sel B, jumlah sel B yang memproduksi antibody meningkat dan adanya hipergamaglobulinemia (Widodo W, 2012).

Virus HIV ini menyerang system kekebalan tubuh, sedangkan sistem kekebalan tubuh bertugas untuk melindungi tubuh dari penyakit apa pun yang setiap hari menyerang tubuh kita. Antibodi adalah protein yang dibuat oleh system kekebalan tubuh ketika benda asing masuk kedalam tubuh (murni dkk, 2016).

Dalam penelitian ini terdapat beberapa faktor yang dapat mempengaruhi hasil penelitian diantaranya pembuatan apusan darah tepi yang kurang baik sehingga peneliti mengalami kesulitan pada saat melakukan pembacaan hasil dan peneliti mengalami kesulitan dalam mendapatkan sampel karena sebagian besar penderita HIV melakukan pengobatan rawat jalan sehingga sulitnya menghubungi dan mengumpulkan pasien tersebut. 
Jurnal Media Analis Kesehatan, Vol. 10, No.1, Juni 2019

http://journal.poltekkes-mks.ac.id/ojs2/index.php/mediaanalis

e-ISSN : 2621-9557

p-ISSN : 2087-1333

\section{KESIMPULAN}

Berdasarkan hasil penelitian yang dilakukan di Laboratorium Hematologi jurusan Analis Kesehatan Poltekkes Makassar dan dapat disimpulkan bahwa dari hasil pemeriksaan jumlah Limfosit pada apusan darah tepi didapatkan hasil $26.66 \%$ yang menunjukkan jumlah Limfosit yang Normal dan $73.33 \%$ yang menunjukkan jumlah Limfosit yang dibawa normal.

\section{SARAN}

Berdasarkan kesimpulan diatas, maka penulis dapat memberikan saran pada peneliti selanjutnya dalam penentuan sampel sebaiknya memperhatikan lama menderita Virus HIV. Dan penulis mengharapkan KTI ini dapat dijadikan sebagai bahan referensi untuk calon peneliti selanjutnya.

\section{DAFTAR PUSTAKA}

Gandasoebrata. R, 2013. Penuntun Laboratorium Klinik. Jakarta: PT. Dian Rakyat

Guindo, O.M., Liu, A., \& Haba, K. 2014. Knowlage, Attitude and Practices of Youth towards HIV/AIDS in Mali, west Afria. Internasional Journal of Advances Physiology and Allied Sciences. .
Handayani W, Haribowo S.A, 2008. Asuhan Keperawatan pada Klien dengan Gangguan Sistem Hematologi. Jakarta: salemba medika.

Hawari D. 2006. Global Effect HIV/AIDS dimensi Psikoreligi. Jakarta: FKUI

Hoffbrand A.V, Pettit J.E, Moss P.A.H,. 2011. Kapita Selekta Hematologi Edisi 4. Jakarta: Kedokteran EGC

Padmasari I.S. 2017. Penderita HIV/AIDS di kota Makassar. Makassar. @www.hivdatingsites.biz

Rahayu I, Rismawanti V, Jaelani K.A. 2017. Hubungan tingkat pengetahuan tentang HIV/AIDS dengan perilaku seksual pernikahan pelajar. Pekan baru, Riau. Journal Endurance.

Subowo. 2010. Imunologi Klinik Edisi ke 2. Jakarta: Sagung Seto.

Tim dosen, 2017. Penuntun Praktikum Hematologi I. Politeknik Kesehatan Kementrian Kesehatan Makassar Jurusan Analis kesehatan.

Widodo W.D.A, 2012. HIV-AIDS from basicto clinical management.Rumah Sakit tropic Infeksi Universitas Airlangga. 